\title{
The effect of feeding silage treated with an inoculum of Lactobacillus plantarum on beef production from growing and finishing cattle
}

\author{
JP Moran, TR Owen \\ ZENECA Bio Products, PO Box 2, Billingham, Cleveland, TS23 1YN, England
}

The positive effects on fermentation of treating forage with bacterial inoculants has been well documented in the titerature (Moran and Owen, Proceedings of the 10th International Conference on Silage Research, Dublin City University, Ireland, Sept 6-8, 1993), however there has been little information published on the effects of these inoculants on animal performance. The purpose of this review is to present a summary of all independent research trials carried out using both growing and finishing beef animals fed untreated and ECOSYL (ECOSUR in France) treated silage. A similar review has recently been published for dairy cow trials (Moran and Owen, Proceedings of the National Conference on Forage Quality, Evaluation, and Utilization, University of Nebraska-Lincoln, USA, April 1315, 1994).

A total of 19 trials studying the effects on beef production (with both growing and finishing cattle) of feeding ECOSYL treated silage are presented. Trials are categorised according to the growth stage of the animal i.e. growing and finishing cattle and by crop type using either grass or alfalfa/maize silage. Dry matter intakes and beef production parameters were analysed statistically using analysis of variance Anova procedures (SAS/STAT, release 6.03, 1988, SAS institute Inc) comparing treatment means as pairs within blocks represented by trials. References and experimental details for all trials are available from the authors on request.

Mean results presented show a trend towards increased silage dry matter intake and a significant $(P<0.01)$ increase in both liveweight and carcass gain for both types of animal regardless of the crop type.

It is concluded that grass, alfalfa or maize silages which had been treated with ECOSYL inoculant gave rise to significant improvements in animal liveweight and carcass gains for both growing and finishing cattle.

\begin{tabular}{|c|c|c|c|c|c|c|}
\hline & \multicolumn{4}{|c|}{ Growing Cattle } & \multirow{2}{*}{\multicolumn{2}{|c|}{$\begin{array}{c}\text { Finishing Cattle } \\
\text { Grass Silage }(\mathrm{n}=9)\end{array}$}} \\
\hline & \multicolumn{2}{|c|}{ Grass Silage $(n=5)$} & \multicolumn{2}{|c|}{ Alfalfa and Maize Silage $(n=5)$} & & \\
\hline & $\begin{array}{l}\text { Silage DM } \\
\text { Intake } \\
\text { (kg/day) }\end{array}$ & $\begin{array}{l}\text { Liveweight } \\
\text { Gain } \\
\text { (kg/day) }\end{array}$ & $\begin{array}{l}\text { Silage DM } \\
\text { Intake } \\
\text { (kg/day) }\end{array}$ & $\begin{array}{l}\text { Liveweight } \\
\text { Gain } \\
\text { (kg/day) }\end{array}$ & $\begin{array}{l}\text { Silage DM } \\
\text { Intake } \\
\text { (kg/day) }\end{array}$ & $\begin{array}{c}\text { Carcass } \\
\text { Gain } \\
\text { (kg/day) }\end{array}$ \\
\hline Control & 4.51 & 0.66 & 7.29 & 1.06 & 6.59 & 0.51 \\
\hline ECOSYL & 4.75 & 0.76 & 8.17 & 1.16 & 6.84 & 0.56 \\
\hline SEM & 0.121 & 0.010 & 0.270 & 0.012 & 0.100 & 0.011 \\
\hline $\mathrm{P}$ & NS & $<0.01$ & $<0.1$ & $<0.01$ & NS & $<0.01$ \\
\hline
\end{tabular}

